Business and Economics Research Journal

Volume 7 Number 42016

pp. $51-66$

ISSN: $1309-2448$

DOI Number: 10.20409/berj.2016422338

\title{
Küresel Ekonomik Krizin Türkiye İşgücü Piyasasındaki Etkileri: Markov Geçiş Analizi
}

\author{
Elif Öznur Acar ${ }^{\mathrm{a}}$
}

\begin{abstract}
Öz: Bu çalışmada, küresel ekonomik krizin Türkiye işgücü piyasası dinamikleri üzerindeki etkileri 2006-2009 Gelir ve Yaşam Koşulları Anketi (GYKA) mikro panel veri seti ve Markov geçiş süreçleri kullanılarak incelenmektedir. Bu amaçla, ücretli/yevmiyeli çalışma, kendi hesabına çalışma, işsiz ve işgücü dışında olma olarak belirlenen dört farklı istihdam durumu arasındaki yıllık bireysel geçişlerin Markov olasılık istatistikleri kriz öncesi ve kriz dönemi karşılaştırılarak incelenmektedir. Daha sonra, krizin farklı işgücü piyasası gruplarını hangi boyutta ve nitelikte etkilediğini incelemek için ise aynı analiz farklı cinsiyet, eğitim ve yaş grupları için ayrı ayrı gerçekleştirilmektedir. Sonuçlar, küresel krizin Türkiye işgücü piyasalarını özellikle ücretli çalışma ve işsizlik kanalları üzerinden olumsuz bir şekilde etkilediğini göstermektedir. Kriz ile birlikte ücretli çalışanların işsiz statüsüne geçiş ve işsizlik durumundan çıkamama olasılıkları toplam ve tüm kesitlerde yükselmiştir. İşgücü dışında olma durumundan ücretli ya da kendi hesabına çalışan durumununa geçiş olasılıklarının düşmüş, ve buna karşılık işsiz durumuna geçiş olasılığı artmıştır. Krizde, işgücü hareketliliği boyut ve nitelikleri açısından en çok zarar görenler kadınlar, düşük vasıflılar ve gençler olmuştur.
\end{abstract}

Anahtar Sözcükler: İşgücü Piyasası Geçişleri, İ̧̧ücü Hareketliliği, Küresel Ekonomik Kriz, Markov Geçiş Süreçleri, Türkiye

JEL Sınıflandırması: J11, J21, J60, J63

\section{The Impact of the Global Economic Crisis on the Turkish Labor Market: A Markov Transition Analysis}

Abstract: This study examines the impacts of the global economic crisis on the dynamics of the Turkish labor market, 2006-2009 Income and Living Conditions Survey (SILC) panel data set and Markov transition analysis. For this purpose, Markov probabilities of annual individual flows between four market labor market states of salaried employment, self-employment, unemployment and inactivity are compared across pre-crisis and crisis period. Further, the analysis is conducted for gender, age and education subcategories to analyze the extent and nature of the crisis on different labor market groups. The results show that the crisis has negatively affected the Turkish labor market, particularly through salaried employment and unemployment channels. During the crisis, the probability of becoming unemployed for salaried workers fell significantly, while the probability of remaining unemployed increased. Moreover, the probability of moving into employment decreased and that into unemployment rose for the inactive group. Women, low skilled and youth are found to be the most negatively affected from the crisis.

Keywords: Labor Market Transitions, Labor Mobility, Global Economic Crisis, Markov Transition Process, Turkey

JEL Classification: J11, J21, J60, J63

${ }^{a}$ Assist. Prof., PhD., Çankaya University, Faculty of Economics and Administrative Sciences, Banking and Finance Department, Ankara, Turkiye, elifoznurkan@cankaya.edu.tr 


\section{Giriş}

Küresel finansal ve ekonomik kriz pek çok ülkede işgücü piyasalarını derinden sarsmış, işsizlik rakamlarının ciddi oranlarda artmasına sebep olmuştur. 2008 yılının ortalarından 2010 yılına kadar belirgin olarak süren krizin etkilerinin nitelik ve niceliği, ülkeden ülkeye, var olan makroekonomik yapı, işgücü piyasası dinamikleri, işgücü düzenlemeleri vb. birçok etmene bağlı olarak farklılık göstermiştir. Buna paralel olarak, küresel krizin farklı ülke piyasalarında doğurduğu sonuçlarını, kapsam ve boyutlarını, mücadele için alınabilecek politika önlemlerini inceleyen geniş bir iktisat yazını oluşmuştur. Bu çalışmaları makroiktisadi ve mikroiktisadi olacak şekilde iki başlık altında değerlendirmek mümkündür. Birinci grupta yer alan çalışmalar toplam makro-veriler üzerinden piyasaları bir bütün olarak ele almaktayken, ikinci grupta yer alan çalışmalar bireysel mikro-verilerin kullanımı ile daha detaylı analizler yapılabilmesine olanak sağlamaktadır.

Bu çalışmada, küresel krizin Türkiye işgücü piyasası dinamikleri üzerindeki etkilerinin mikro işgücü verileri kullanılarak incelenmesi amaçlanmaktadır. Bu doğrultuda, farklı işgücü piyasası halleri arasındaki hareketliliğinin hangi boyut ve nitelikte değiştiği, kriz öncesi ve kriz dönemi karşılaştırması yapılarak incelenmektedir. Bu çerçevede, Türkiye İstatistik Kurumu (TÜiK) tarafindan gerçekleştirilen 2006-2009 Gelir ve Yaşam Koşulları Anketi (GYKA) mikro panel veri seti kullanılarak, farklı işgücü piyasası halleri arasındaki geçiş olasılıkları, Markov geçiş süreçleri ile hesaplanmaktadır. Markov zincir modelleri örnek kişilerin tam geçiş tarihleri bilgisinin olmadığı, sadece kesikli zaman noktalarında gözlemlenebildiği durumlarda bireylerin farklı işgücü piyasası durumları arasındaki geçiş olasılıklarının hesaplanabilmesini sağlamaktadır (Fabrizi ve Mussida, 2009). Çalışmada ilk olarak ücretli/yevmiyeli çalışma, kendi hesabına çalışma, işsiz ve işgücü dışında olma olarak belirlenen dört farklı istihdam durumu arasındaki yıllık bireysel geçişlerin olasılık istatistikleri toplam örneklem için hesaplanmaktadır. Daha sonra, Ercan (2010)'un küresel krizin en ağır biçimde hisseden kesimin işgücünün en dezavantajlı kesimleri olduğu saptamasından hareketle, ekonomik krizin farklı işgücü piyasası gruplarını hangi boyutta ve nitelikte etkilediğini incelemek için ise aynı analiz kadın ve erkek; düşük, orta ve yüksek vasıflı; 15-24, 25-34, 35-54 ve 55-64 yaş gruplarındaki bireyler için ayrı ayrı sunulmaktadır.

$\mathrm{Bu}$ çalışma ekonomik krizlerin işgücü piyasalarına etkisi yazınına üç temel katkı yapmayı hedeflemektedir. Bunlardan birincisi, Türkiye örnekleminde konuyu değerlendirmek ve karşılaştırmalara temel hazırlamaktır. İinci olarak, literatürdeki toplamcı yaklaşımla yapılan çoğu çalışmanın aksine, mikro panel veri setleri ve teknikleri kullanılarak daha detaylı, kapsamlı ve açıklayıcı bir analiz ortaya konulmaktadır. Veri yetersizliği sebebiyle, Türkiye işgücü piyasalarındaki işgücü hareketliliğini mikro veriye dayalı olarak inceleyen çalışma sayısı sınırıdır. Bu alanda yapılan ilk çalışma, Taş̧̧ı ve Tansel (2005) tarafindan Hanehalkı İsgücü Anketi 2000 ve 2001 panel verileri kullanarak, Markov modeli çerçevesinde cinsiyet, medeni durum, kır-kent kırılımlarında işgücü hareketliliklerinin incelendiği makaledir. Benzer yaklaşımı kullanarak, Tansel ve Kan (2012) Türkiye işgücü piyasasında kayıtdışı istihdamın diğer istihdam ve istihdam dışı işgücü piyasası durumları arasındaki geçişlerin yapısını ve boyutlarını 2006-2009 Gelir ve Yaşam Koşulları panel verisi ile Markov geçiş analizi kullanarak incelemiştir. Yine aynı çalışmada, çoklu logit regresyonu ile her bir geçişin olasılığı bireysel, mesleki, hanehalkı özellikleri ile açıklanmaya çalışıımıştır. Kaya-Bahçe ve Memiş (2014) ise 2006-2009 Gelir ve Yaşam Koşulları Anketi panel verisini kullanarak işsizliğin tanımında yer alan iş arama kriterinin geçerliliğini incelemişlerdir. Nüfusun işgücünde yer almayan kesimi işgücü piyasasına yakınlığına göre iş aramayıp çalışmak isteyen ve aktif olmayan olarak yeniden sınıflandırılarak, iş aramayıp çalışmak isteyenlerin resmi olarak işsiz sayılan gruptan farklı bir gruba karşılık gelip gelmediği test edilmiştir. Alcan vd. (2015), yine Gelir ve Yaşam Koşulları anketinin 2008-2011 panel veri seti üzerinden altı farklı statü olarak tanımladıkları işgücü piyasası durumu arasındaki geçişlerin eğilimlerini ve bu geçişlerin yapısal belirleyicilerini ele almışlardır. Bu çalışmayı öncekilerden ayıran temel özellik işgücü hareketliliğini kriz çerçevesinde incelemektir. Krizin cinsiyet, yaş ve eğitim kırılımlarındaki işgücü hareketliliklerini ne yönde ve boyutta etkilediği ortaya konulmaya çalışılmaktadır.

Bu doğrultuda, makalenin ikinci bölümünde küresel krizin Türkiye işgücü piyasalarında istihdama olan etkisi makro boyutuyla genel çerçeveyi oluşturacak şekilde değerlendirilmektedir. Üçüncü bölümde çalışmada kullanılan veri seti ve metodoloji tanıtılmakta, dördüncü bölümde ise işgücü piyasası durumları arasındaki Markov geçiş olasılıkları rapor edilerek, sonuçlar üzerinden krizin etkileri tartışılmaktadır. Son bölümde çalışmanın temel sonuçları ve politika önermeleri sunulmaktadır. 


\section{Küresel Krizin Gölgesinde Türkiye İşgücü Piyasaları}

Türkiye kriz öncesi ekonomik koşulları sebebiyle küresel ekonomik durgunluktan en çok etkilenen ülkeler arasında yer almıştır (UNCTAD, 2008; Erdoğdu, 2010; Kılıç ve Bülbül, 2012). 2008 yılının son çeyreğinden itibaren daralmaya başlayan ekonomide Gayri Safi Yurtiçi Hasıla (GSYH) 2009 yılına gelindiğinde ilk çeyrekte yüzde -14.7, ikinci ve üçüncü çeyreklerde sırasıyla yüzde -7,9 ve -3,3 küçülme kaydetmiştir. Reel ekonomiye yayılan krizin en ağır yansımaları işletmelerin ölçek küçültmesi hatta kapanması, yeni istihdam olanaklarının büyük ölçüde azalması, ücret azalışları veya iş kayıpları ile bireylerin tüketim harcamalarını kısmaları gibi kanalllar üzerinden istihdam üzerinde hissedilmiştir (Gökbunar vd, 2016).

İşsizlik göstergeleri krizlerin etkilerini ölçmede başvurulan en önemli araçlardan biridir. Küresel ekonomik kriz de ilk başta mali kriz ile başlayıp, reel ekonomik krize, ardından yüzyılın en büyük ve derin istihdam krizine dönüşmüştür. Türkiye işgücü piyasası da ne yazık ki bunun en çarpıcı örneklerinden biri olmuştur. 2005-2008 yılları boyunca yüzde 10 bandında seyreden işsizlik oranı, 2009'un ilk çeyreği ile birlikte yüzde 16'ya, tarım dışı olarak hesaplandığında ise yüzde 19'a kadar tırmanmıştır. Erdoğdu (2010) 2009 Şubat dönemi için eksik istihdamı ve iş bulması halinde çalışmaya hazır olanları da ekleyerek gerçek atıl işgücü ya da türetilmiş işsizlik oranını yüzde 29,2 olarak hesaplamıştır.

İssizlik oranının 2005-2013 yılları arasındaki trendi incelendiğinde, 2009 yılında yıllık ortalamada yüzde 14'e kadar tırmandığı görülmektedir. Kriz ertesinde 2010 yılında yüzde 11,9' a gerileyen oran, düşüşüne devam ederek 2013 yıında, 2005-2007 yılları arasında seyrettiği yüzde 10 bandının da altına inerek yüzde 9,7 olarak gerçekleşmiştir. Yaprak (2009) işsizliğin kriz döneminde bu denli artmasını kurulan şirket sayısındaki önemli azalma ve kapanan işyeri sayısındaki artş̧a bağlamaktadır. 2009 yılı Mayıs ayında, 2008'in aynı ayına göre kurulan şirket ve kooperatif sayısı yüzde 19,4 ve kurulan ticaret unvanlı iş yeri sayısı yüzde 24,8 azalmıştı (Yaprak, 2009: 46). Öte yandan, kriz döneminde uzun dönemli işsizlerin (6 ay ve daha uzun süre işsiz olanların) sayısında da hızlı bir artş̧ yaşanmıştır (Yeldan, 2010).

İssizlik oranının cinsiyet kırılımı ise, kriz döneminde erkeklerde yüzde 13,9 ile zirve yapan oranın kadınlarda yüzde 14,3 ile en yüksek seviyeyi gördüğünü göstermektedir. Bir başka nokta ise, erkeklerde işsizlik oranının kriz ertesinde toparlanmasının kadınlardakine kıyasla çok daha hızı gerçekleştiğidir. Nitekim, 2013 yılında erkeklerde işsizlik oranı yüzde 8,7 ile son on yılda gördüğü en düşük seviye olan yüzde 9,9'unda altına kadar inmiştir. Kadın işsizlik oranında ise daha ağır olmakla birlikte kriz ertesi bir toparlanma yaşanmış, ancak 2013'te tekrar 1 puanlık kötüleşme görülmüştür.

Şekil 1. 2005-2013 Dönemi Türkiye İşsizlik Oranı (Toplam, Erkek, Kadın. \%)

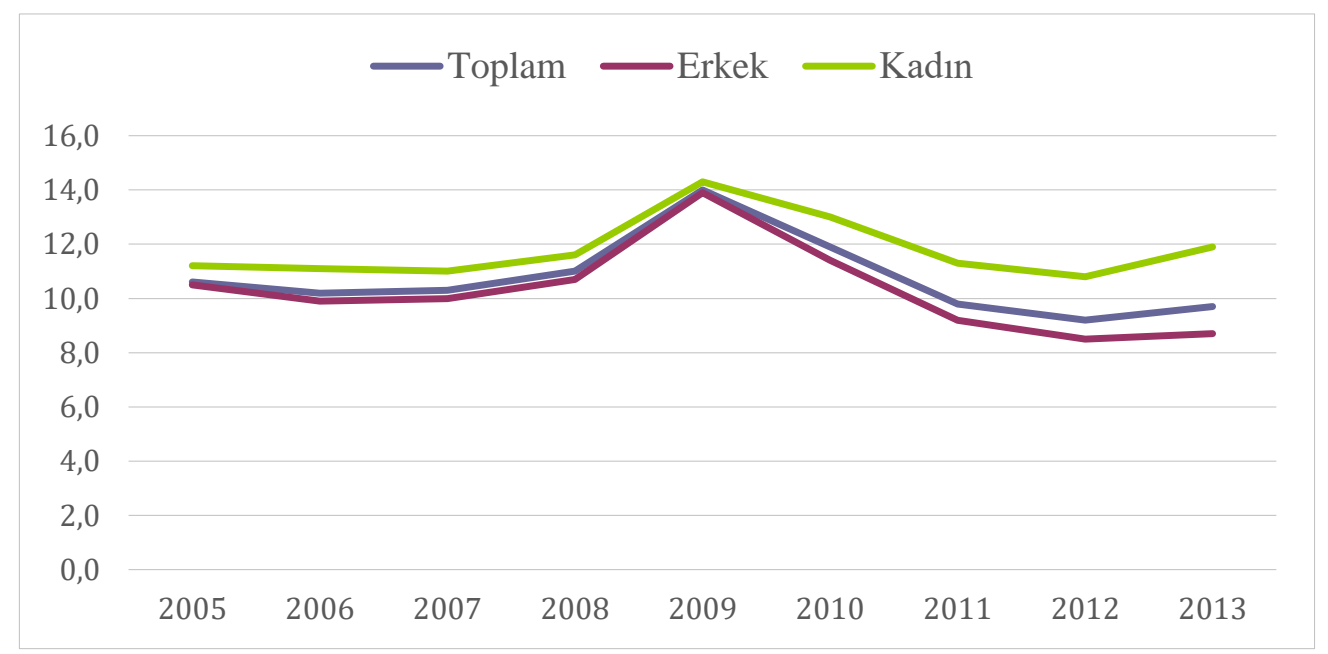

Kaynak: TÜiK İşgücü İstatistikleri ve yazarın kendi hesaplamaları. 
Kadınların hem erkeklere hem de benzer ülkelerdekine kıyasla işgücüne katılımının son derece düşük olduğu Türkiye ekonomisinde, kadın işgücüne katılım oranı kriz döneminde hem kır hem kentte artmıştır. İstihdam oranlarının da aynı şekilde yükselmesi, kriz döneminde ilave işgücü etkisinin varlığına işaret olarak değerlendirilmektedir (Ercan, 2010). Hanedeki erkek bireylerin iş kayıpları ya da ücret azalışları yaşamaları, kadınları işgücü piyasasında daha aktif hale getirmiştir.

Kriz dönemindeki işsizlik probleminin göze çarpan bir diğer boyutu eğitim seviyesi kırılımında gözlenmiş, üniversite mezunları diğer eğitim seviyesindeki bireylere nazaran daha olumsuz etkilenmişlerdir (Yeldan, 2010). Bu öngörüden hareketle, çalışmanın ilerleyen bölümlerinde krizin eğitim kompozisyonuna bağlı olarak işgücü hareketliliğini ne şekil ve boyutta etkilediği konusu detaylı bir biçimde analiz edilecektir.

Şekil 2. 2006-2010 Dönemi Türkiye İşsizlik Oranı (Yaş gruplarına göre, \%)

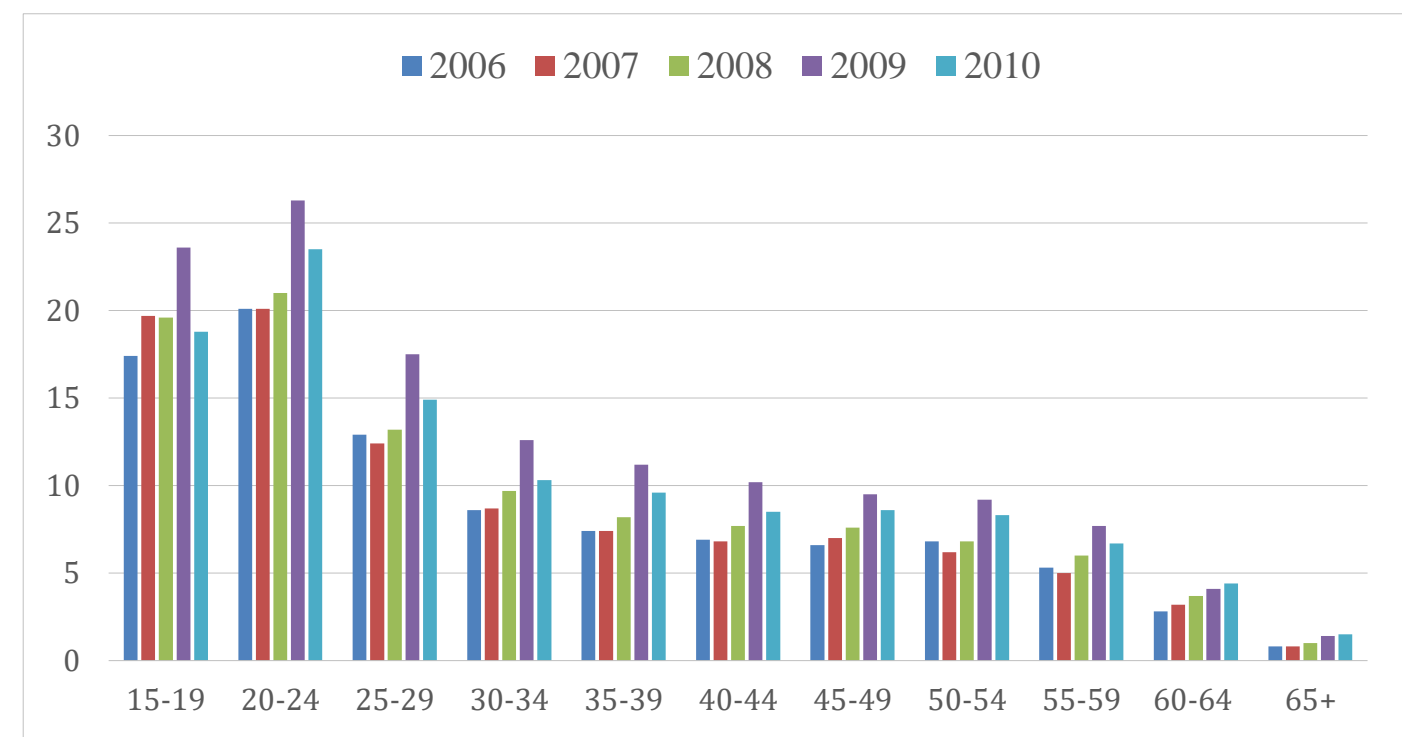

Kaynak: TÜiK İşgücü İstatistikleri ve yazarın kendi hesaplamaları.

İşsizliğin yaşa göre dağılımına baktığımızda, genç işsizliğinin Türkiye işgücü piyasalarında oldukça ciddi bir problem olduğunu görmekteyiz (Şekil 2). 2006 yılından itibaren genel olarak tüm yaş grupları için artı̧̧ eğiliminde olan işsizlik oranı, 2009 yılında tüm gruplar için trendin çok daha üstünde ortalamada yüzde 30 civarında bir yükselme kaydetmiştir. Etki orta yaş grubunda en belirgin şekilde hissedilirken, ileri yaş grubunda görece daha sınırlı kalmıştır.

\section{Veri ve Yöntem}

Çalışmada TÜiK'in 2006, 2007, 2008 ve 2009 yıllarında gerçekleştirdiği Gelir ve Yaşam Koşulları Araştırması (GYKA) mikro panel verisi kullanılmaktadır. GYKA veri setinin yeni olması, panel niteliği ve zengin bilgi içeriği çalışmayı bugüne kadar yapılan Türkiye işgücü piyasası çalışmalarından ayıran unsurların başında gelmektedir. Ankette, hanehalkı ve bağlı fertlerin çalışma statüsü, çalıştğı sektör, yaşam koşulları, iş özellikleri, çalışma saatleri, emek ve diğer gelirleri, demografik özellikleri ve sosyoekonomik şartları ile ilgili detaylı bilgiler yer almaktadır. Anket sonuçları her yıl kesit-veri ve panel-veri olarak iki şekilde yayınlanmaktadır.

Mikro düzey panel veri ve çok durumlu (multi-state) stokastik modellerin kullanılmaya başlanması ile birlikte işgücü piyasası yazınında önemli bir paradigma kayması yaşanmıştır. Bu çerçevede bilhassa öne çıkan Markov Zincir Modeli bireylerin farklı işgücü piyasası durumları arasındaki geçişlerinin izlenebilir hale gelmesine olanak sağlamıştı. Bu yöntemle yapılan ilk çalışma, Maloney (1999)'nin panel veri kullanarak, Meksika işgücü piyasalarında sektörler arası geçişlerin yapısını incelediği çalışmasıdır. Panel veri setlerinin giderek yaygınlaşması ile birlikte, bu çalışmayı takiben pek çok ülke için benzer işgücü hareketliliği çalışmaları yapılmış, geniş bir literatür oluşmuştur (Gong et al., 2004; Bosch and Maloney, 2010; Bernabe and Stampini, 2009; Duryea et al., 2006) 
Fabrizi ve Mussida (2009)'nin ifade ettiği gibi Markov zincir modelleri örnek kişilerin tam geçiş tarihleri bilgisinin olmadığı, sadece kesikli zaman noktalarında gözlemlenebildiği durumlarda geçiş olasılıklarının hesaplanabilmesini sağlamaktadır. Çalışmada ilk olarak Markov geçiş süreçleri çerçevesinde farklı istihdam durumları arasındaki yıllık çalışan geçişlerinin olasıılıkları önce toplam, sonra farklı cinsiyet, eğitim ve yaş grupları örneklemleri için ayrı ayrı hesaplanacaktir. Bosch ve Maloney (2007)' de bahsedildiği gibi işgücü durumu rassal geçişlerin olduğu bir süreç olarak tanımlandığında, belirli işgücü durumları arasındaki geçişlerin olasılıkları Markov geçiş matrisleri şeklinde tanımlanabilmektedir.

Buna göre, $X_{t}$ rassal sürecinin t zamanına kadarki tüm geçmişini şöyle ifade edilebilir:

$$
\left\{X_{t}=x_{t}, X_{t-1}=x_{t-1}, \ldots, X_{1}=x_{1}\right\}
$$

Herhangi bir kesikli durum uzayı $K=\{1, \ldots, K-1\}$ üzerinde tanımlı $X_{t}^{\prime}$ nin farklı zamanlarda aldığı değerlerin koşullu olasılıkları aşağıdaki Markov özelliğini gösterdiğinde $X_{t}$ rassal süreci birinci dereceden Markov Zinciri (Markov chain) olarak adlandırımaktadır:

$$
\operatorname{Pr}\left(X_{t}=k \mid X_{t-1}, \ldots, X_{1}\right)=\operatorname{Pr}\left(X_{t}=k \mid X_{t-1}\right)
$$

Markov özelliği olarak bahsi geçen durum söz ile ifade edilirse, $X_{t}$ 'nin şimdiki değeri bilindiğinde geçmişte almış olduğu değerlerin gelecekte alacağı değerlerin koşullu olasılığı üzerinde hiçbir etkisinin olmamasıdır. Bir diğer deyişle, şimdiki zaman verisi olduğunda gelecek geçmişten bağımsızdır.

$X_{t}$ bir Markov zinciri ise ve $\mathrm{j}, \mathrm{k} \in\{K\}$, aşağıdaki koşullu olasılık:

$$
p_{k j}(t, t+1)=\operatorname{Pr}\left(X_{t+1}=j \mid X_{t}=k\right) \forall t \text { ve } j, k \in K
$$

t zamanında, $\mathrm{k}$ durumundan j durumuna geçmenin geçiş olasılığı olarak tanımlanmaktadır. Bu geçiş olasılıklarının zamandan bağımsız ise Markov zinciri zaman-homojen olarak ifade edilmektedir:

$$
p_{k j}(t, t+n)=\operatorname{Pr}\left(X_{t+n}=j \mid X_{t}=k\right) \forall t, n \text { ve } j, k \in K
$$

$K=\{1, \ldots, K-1\}$ sonlu durum uzayı içerisindeki geçiş olasılıkları aşağıdaki gibi bir kesikli zaman geçiş olasılıkları matrisi şeklinde gosterilebilmektedir:

$$
P=\left[\begin{array}{ccc}
p_{00} & \cdots & p_{0 K} \\
\vdots & \ddots & \vdots \\
p_{K 0} & \cdots & p_{K K}
\end{array}\right]
$$

$\left[\begin{array}{llll}p_{k 0} & p_{k 1} & \ldots & p_{k K}\end{array}\right]$ ile verilen satır $i$ durumundan gerçekleştirilen tüm çıkışların olasılıklarını göstermektedir ve bu sebeple de toplamı 1 olmak zorundadır. Genelde, bu şekilde her satırın negatif olmayan sayılardan oluştuğu ve bu sayıların toplamının bire eşit olduğu matrislere Geçiş Olasılıkları Matrisi, ya da kimi zaman Stokastik Matris ismi verilmektedir.

P matrisini tahmin etmek için ilk olarak aşağıdaki istatistikler hesaplanmaktadır:

$N_{k j} \triangleq k$ durumundan $j$ durumuna gerçekleşen toplam geçiş sayısı

$N_{k .} \triangleq \sum_{t \in K} N_{s t}=k$ durumundan başlayarak gerçekleşen toplam geçiş sayısı

$N_{. j} \triangleq \sum_{s \in K} N_{s t}=j$ durumuna gerçekleşen toplam geçiş sayısı 
$N \triangleq \sum_{k j \in K} N_{k j}=$ toplam geçiş sayısı

Böylelikle;

$$
\begin{aligned}
& N_{k .}=\sum_{j} N_{k j}, \\
& N_{. j}=\sum_{j} N_{k j}, \\
& N=\sum_{k \in K} N_{k .}=\sum_{j \in K} N_{. j}
\end{aligned}
$$

Bu çerçevede, $p_{k j}$ geçiş olasıllı̆ı Maksimum Olabilirlik tahmincisi olan $p_{k j}=\frac{N_{k j}}{N_{k}}$ ile kolayca tahmin edilebilmektedir.

Markov zincir modelini çalışmamıza özgü yapılandırdığımızda $X_{t}$ herhangi bir bireyin t zamanındaki işgücü piyasası durumunu ifade etmek için kullanılmaktadır. Durum uzayı K dört adet olarak tanımladığımız işgücü piyasası durumlarını kapsamaktadır: Ücretli/Yevmiyeli Çalışan (S), Kendi Hesabına Çalışan (SE), İşsiz (U), İ̧̧gücüne Dahil Olmayan (N). Bu grupların tanımları yapılırken TÜiK tarafindan verilen çerçeveye mümkün olduğunca sağdik kalinmaya çalışılacaktır: kişilerdir.

Ücretli/Yevmiyeli Çalışan (S): Esas işindeki durumu ücretli/maaşlı veya yevmiyeli statüsünde olan

Kendi Hesabına Çalışan (SE): Esas işindeki durumu işveren veya kendi hesabına çalışan statüsünde olan kişilerdir.

İşiz (U): İşi olmayan, iş aramak için son üç ay içerisinde iş arama kanallarından en az birini kullanmış ve iki hafta içinde işbaşı yapabilecek durumda olan kurumsal olmayan çalışma çağındaki kişilerdir.

İşgücüne Dahil Olmayan (N): İstihdamda olmayan veya işsiz olmayan kurumsal olmayan çalışma çağındaki nüfustur. Bu gruba dahil olanlar, iş aramayıp çalışmaya hazır olanlar, iş bulma ümidi olmayanlar, mevsimlik çalışanlar, ev işleri ile meşgul olanlar, öğrenci ve emekli olanlar, ve çalışamaz halde olanlardır.

Çalışmamızda, $p_{k j}$ incelenen dönemin başlangııında $k$ işgücü durumunda olan bir kişinin dönem sonunda $j$ işgücü durumunda olması olasılığını ifade etmektedir. İlk olarak, söz konusu $p_{k j}$ olasılıkları Gelir ve Yaşam Koşulları Araştırması'nın 2006-2007, 2007-2008, 2008-2009 panel verilerinin ayrı ayrı olarak tahmin edilmiştir. 2006-2007 ve 2007-2008 işgücü piyasası Markov geçiş olasılıkları birbirine çok benzer olmakla birlikte, 2008-2009 yılları arası geçiş olasılıkları ilk iki rejimdekilerden çok daha farklı bir tablo ortaya koymaktadır. Iktisadi literatürde, ekonomik kriz iki çeyreklik dönem boyunca Gayri Safi Yurt İçi Hasıla (GSYiH) büyüme oranının negatif olarak gerçekleştiği dönemleri ifade etmek için kullanılmaktadır. Türkiye için söz konusu dönemdeki GSYiH büyüme oranlarına bakıldığında, 2008'in ikinci çeyreği ile başlayarak 2009'un ikinci çeyreğine kadar negatif olduğu görülmektedir. Bu rakamlar çerçevesinde, Türkiye'nin küresel krizin etkisiyle ekonomik durgunlukta olduğu dönemi 2008 yılının üçüncü çeyreği ile 2009 yılının ikinci çeyreği arası olarak kabul etmek mümkündür. GYKA verilerinin her yıl Nisan-Temmuz ayları arasında derlendiği de göz önüne alındığında, krizin etkilerinin 2008-2009 yılları arası işgücü geçişlerinde gözlemlenebileceği görülmektedir. Bu sebeple de, çalışmamı temel olarak kriz öncesi ve sonrası şeklinde iki rejimi ele almaktadır. illk olarak, birbirine çok benzer olasılıklar gösteren 2006-2007 ve 2007-2008 olasılıklarının ortalamaları alınarak, kriz öncesi dönem için sunulmuştur. 2008-2009 Markov geçiş olasılıkları ise GSYiH küçülmesinin 2008 yılında başlayıp, 2009 yılında devam etmesi göz önünde bulundurularak kriz dönemini gösteriyor olarak kabul edilmiştir. Ortaya çıkan geçiş olasılıkları matrisleri, işgücü piyasasındaki hareketlerinin hangi yönde ve boyutta 
olduklarını oldukça detaylı bir şekilde ortaya koymaktadır. Kriz öncesi ve kriz döneminde emek piyasasındaki işgücü geçişleri karşılaştırılarak, krizin Türkiye işgücü piyasaları üzerindeki etkilerinin gözlemlenmesi amaçlanmıştır. Toplam gözlem sayıları 2006-2007 geçişleri için 18343, 2007-2008 için 18830 ve 2008-2009 için 19344 şeklindedir. Dört işgücü piyasası için ayrı ayrı bakıldığında, 2006-2007 geçişleri için ücretlilerde 4654, kendi hesabına çalışanlarda 4264, işsizlerde 977 ve işgücü dışında olanlarda 8448 gözlem bulunmaktadır. Bu rakamlar 2007-2008 geçişlerinde sırasıyla 5222, 4270, 830 ve 8508 iken; 2008-2009 geçişlerinde 5632, 4152, 989 ve 8571 olarak alınmıştır.

İlk olarak tüm örneklem için gerçekleştirilen Markov geçiş analizi, ardından cinsiyet ayrımı gözetilerek kadın ve erkek örneklemler için ayrı ayrı olarak tekrarlanmıştır. Ardından eğitim/beceri seviyesinin kriz dönemindeki işgücü geçişkenliği etkisini incelemek adına, örneklem düşük, orta ve yüksek vasıflı olacak şekilde üç eğitim/vasıf grubuna ayrılmıştır. Bu sınıflandırmada okur-yazar olmayanlar, okur-yazar olup bir okul bitirmeyenler ile ilkokul mezunu olanlar düşük vasıf grubunu; ortaokul, mesleki ortaokul ve ilköğretim mezunları ile genel lise mezunları orta vasıf grubunu; mesleki veya teknik lise ile yüksekokul, fakülte ve üzeri eğitimi tamamlamış bireyler yüksek vasıf grubunu oluşturmaktadır. Benzer şekilde, kriz-yaş etkisini analizi için örneklem 15-24, 25-34, 35-54 ve 55-64 yaş gruplarına ayrılarak, Markov geçiş olasılıkları hesaplanmıştır.

\section{Markov Analizi ve Geçiş Olasılıkları}

Tüm örneklem için kriz öncesi ve kriz dönemi işgücü piyasası durumları arasındaki Markov geçiş olasılıkları Tablo 1'de gösterilmektedir.

Tablo 1. Markov Geçiş Olasılıkları $\left(P_{\mathrm{ij}}\right)(\%)$ - Tüm örneklem

\begin{tabular}{|c|c|c|c|c|c|c|c|c|}
\hline \multirow{2}{*}{$\begin{array}{l}\text { Köken/ } \\
\text { Varış }\end{array}$} & \multicolumn{4}{|c|}{$\underline{K r i z ~ O ̈ n c e s i ~ D o ̈ n e m ~}^{5}$} & \multicolumn{4}{|c|}{$\underline{\text { Kriz Dönemi }}^{6}$} \\
\hline & $S^{1}$ & $\mathrm{SE}^{2}$ & $\mathbf{U}^{3}$ & OLF $^{4}$ & S & SE & U & OLF \\
\hline $\mathbf{S}$ & 84,16 & 4,12 & 5,51 & 6,22 & 81,73 & 4,72 & 7,71 & 5,84 \\
\hline SE & 5,26 & 84,43 & 1,67 & 8,65 & 3,78 & 88,32 & 1,52 & 6,38 \\
\hline $\mathbf{U}$ & 39,47 & 7,85 & 29,17 & 23,51 & 32,96 & 8,09 & 36,10 & 22,85 \\
\hline OLF & 4,79 & 4,70 & 2,96 & 87,55 & 3,76 & 3,62 & 3,40 & 89,23 \\
\hline $\mathbf{P}_{\mathrm{.j}}$ Total & 27,68 & 23 & 4,61 & 44,71 & 27,96 & 22,35 & 5,92 & 43,78 \\
\hline
\end{tabular}

Kaynak: GYKA 2006-2009 (Yalnızca panel gözlemler) ve yazarın kendi hesaplamaları.

Notlar: ${ }^{1} \mathrm{~S}$ : Ücretli veya yevmiyeli çalışan ${ }^{2} \mathrm{SE}$ : İşveren veya kendi hesabına çalışan ${ }^{3} \mathrm{U}$ : İş̧̧iz

${ }^{4}$ OLF: İşgücüne katılmayan ${ }^{5} 2006-2007$ ve 2007-2008 geçiş olasılıklarının ortalaması

${ }^{6}$ 2008-2009 geçiş olasılıkları

Tabloda ilk olarak dikkat çeken krizle birlikte piyasada genel olarak işgücü geçişkenliğinin azaldığıdır. Bunun yanında, çalışma hallerinden işsizlik haline geçiş ve işsizlik halinde kalış olasılıkları da belirgin şekilde yükselmiş olarak görülmektedir.

Daha detaylı bir analiz için, kişilerin işgücü piyasasındaki statülerini koruma eğilimlerinde bir değişiklik olup olmadığına bakmak anlamlı olacaktır. 2006-2007 ve 2007-2008 yılları arasındaki geçişlerin olasılık ortalamalarına bakıldığında, ücretli/yevmiyeli ile kendi hesabına çalışan çalışan statüsünde kalma olasılıkları yaklaşık yüzde 84 olarak hesaplanmaktadır. Krizle birlikte, bu oranları ilkinin yüzde 81 'lere gerilerken ikincisinin yüzde $88^{\prime}$ e çıktığı görülmektedir. İki çalışma durumu arasındaki bu fark krizin ücret karşılığı çalışanlarda işsiz kalma olasılı̆̆ını arttırma, kendi hesabına çalışanlarda ise işsiz kalma olasılığını etkilemeyip işgücüne dışına çıkış olasılığını azaltma yönünde etki yaratmış olmasından kaynaklanmaktadır. $t=0$ 'da ücret karşıı̆ı̆ı çalışan birinin, $\mathrm{t}=1$ 'de de ücretli çalışan olma olasııı̆ıının krizle birlikte azalmasının temel nedeni özel sektördeki işten çıkarmalardır. Kendi hesabına çalışanların, bu konumlarını koruma eğilimlerinin arttğı yönündeki bulguyu yorumlarken Türkiye'de bu gruptaki çalışanların statü olarak bakıldığında neredeyse tamamının ücretli bir iş arayışı içinde olduğunu göz önüne almak faydalı olacaktır. Kriz döneminde ücretli bir iş bulma ihtimali azaldığı için kendi hesabına çalışanların bu statülerini koruma ihtimalleri artmıştır.

İşsiz bireylerin kriz öncesi ve sonrası piyasa dinamiklerine detaylı bakıldığında, kriz öncesi dönemde ortalamada yüzde 40 civarında seyreden ücretli/yevmiyeli çalışmaya başlama olasılığı, krizle birlikte yüzde 
33'e kadar gerilemiştir. Öte yandan, kendi hesabına çalışma ya da işgücü dışına geçiş olasılıkları krizle birlikte neredeyse hiç değişmemiştir.

Bir diğer dikkat çekici sonuç, işsizlikten çıkamama ihtimalinin kriz öncesi dönemdeki yüzde 29.17 seviyelerinden kriz etkisi ile yüzde 36'nın üstüne çıkmış olduğudur. Faklı bir ifadeyle, bir dönem işsiz olan birinin sonraki dönemde de işsiz olma intimali krizle birlikte önemli ölçüde artmıştr. Bu durum krizin işsizliğin süresini arttırıcı bir etkisinin olduğunu göstermektedir. Bulgular bütünüyle değerlendirildiğinde, krizin Türkiye işgücü piyasasında işsizlik kanalıyla ciddi oranda olumsuz etki yaratmış olduğunu kanıtlamaktadır.

İşgücü dışında olanların, bir sonraki dönem yine işgücü dışında kalma ihtimalleri ise kriz etkisinde sınırlı bir yükselme kaydetmiştir. İşgücü dışında olanların hem ücretli/yevmiyeli hem de kendi hesabına çalışan statüsünde çalışmaya başlama olasılıkları yaklaşık 1 puan düşerken, işgücü piyasasına girip iş bulamama ve işgücü dışında kalma olasılıkları da artmıştır. Teorik ve ampirik iktisat yazınında, işgücü dışındaki bireylerin bir kesiminin krizle birlikte ücretli, kendi hesabına çalışan ya da işsiz statüsünde işgücüne dahil olması beklenir. Ancak, Tablo 1'deki veriler ışığında bu durumun Türkiye'de geçerli olmadığı sonucu ortaya çıkmaktadır. Bu durum aynı zamanda kriz dönemlerinin, işgücü dışında olanların iş aramaya başlamaları için uygun zamanlar olmadığını da göstermektedir. Daha detaylı araştırmalar gerektirmekle birlikte, kriz dönemlerinde ortaya çıkan yeni pozisyonların halihazırda işgücü piyasasında aktif olan bireyler tarafindan doldurulması olasılığının daha yüksek olduğunu işaret etmektedir.

Krizin işgücü piyasasındaki etkileri genel değerlendirmenin yanında, cinsiyet, yaş ve eğitim kırılımları göz önüne alınarak yapıldığında daha kapsamlı bir tablo ortaya koymaktadır. Bu bağlamda, ilk olarak cinsiyet ayrımı incelenmiştir. Tablo 2 ve Tablo 3 işgücü piyasasındaki Markov geçiş olasılıklarını sırasıyla erkekler ve kadınlar için ayrı ayrı göstermektedir.

Tablo 2. Markov Geçiş Olasılıkları $\left(P_{i j}\right)(\%)$ - Erkek

\begin{tabular}{|c|c|c|c|c|c|c|c|c|}
\hline \multirow{2}{*}{$\begin{array}{l}\text { Köken/ } \\
\text { Varış }\end{array}$} & \multicolumn{4}{|c|}{ Kriz Öncesi Dönem } & \multicolumn{4}{|c|}{ Kriz Dönemi } \\
\hline & S & SE & U & OLF & $S$ & SE & U & OLF \\
\hline$S$ & 85,93 & 4,69 & 5,86 & 3,53 & 83,79 & 5,11 & 7,86 & 3,23 \\
\hline SE & 7,71 & 86,00 & 2,41 & 3,88 & 6,02 & 88,78 & 2,09 & 3,11 \\
\hline U & 44,03 & 9,26 & 32,92 & 13,80 & 36,97 & 9,61 & 39,59 & 13,83 \\
\hline OLF & 9,77 & 5,55 & 6,36 & 78,34 & 8,1 & 3,56 & 7,29 & 81,05 \\
\hline $\mathbf{P}_{\mathrm{j} j}$ Total & 45,62 & 27,71 & 7,09 & 19,58 & 45,57 & 27,35 & 8,59 & 18,49 \\
\hline
\end{tabular}

Kaynak: GYKA 2006-2009 (Yalnızca panel gözlemler) ve yazarın kendi hesaplamaları.

Notlar: Bakınız Tablo 1.

Tablo 3. Markov Geçiş Olasılıkları $\left(P_{i j}\right)(\%)$ - Kadın

\begin{tabular}{|c|c|c|c|c|c|c|c|c|}
\hline \multirow{2}{*}{$\begin{array}{l}\text { Köken/ } \\
\text { Varış }\end{array}$} & \multicolumn{4}{|c|}{ Kriz Öncesi Dönem } & \multicolumn{4}{|c|}{ Kriz Dönemi } \\
\hline & $\mathbf{S}$ & SE & U & OLF & S & SE & U & OLF \\
\hline $\mathbf{S}$ & 77,54 & 2,02 & 4,24 & 16,22 & 74,65 & 3,39 & 7,17 & 14,8 \\
\hline SE & 2,04 & 82,35 & 0,68 & 14,93 & 0,58 & 87,66 & 0,7 & 11,05 \\
\hline U & 25,91 & 3,67 & 18,01 & 52,42 & 23,84 & 4,64 & 28,15 & 43,38 \\
\hline OLF & 3,47 & 4,48 & 2,06 & 90,00 & 2,67 & 3,63 & 2,42 & 91,28 \\
\hline $\mathbf{P}_{\mathrm{j} j}$ Total & 11,68 & 18,80 & 2,40 & 67,13 & 11,96 & 17,8 & 3,49 & 66,74 \\
\hline
\end{tabular}

Kaynak: GYKA 2006-2009 (Yalnızca panel gözlemler) ve yazarın kendi hesaplamaları.

Notlar: Bakınız Tablo 1. 
Aslında, kriz etkisinden bağımsız olarak ilk değerlendirme yapıldığında da erkek ve kadın örneklem için oldukça farklı işgücü hareketliliği yapısı olduğu net bir şekilde ortaya çıkmaktadır. Örneğin, 2006-2007 ve 2007-2008 yıllarının ortalamalarına bakıldığında, erkeklerde ücretli/yevmiyeli çalışmaya devam etme olasılığının kadınlardakinin yaklaşık 10 puanın üzerinde olduğu görülmektedir. Yine, tablolarda en çok dikkat çeken husus, kadınların işgücü dışına çıkma yada işgücü dışında kalmaya devam etme olasılıklarının erkeklerinkine nazaran ciddi ölçüde yüksek olduğudur. Ücret karşılığı çalışma durumundan işgücüne çıkış olasılı̆̆ı erkeklerde yüzde 3,53, kadınlarda yüzde 16,22; kendi hesabına çalışmayı bırakıp işgücü dışında kalma olasılı̆̆ı erkeklerde yüzde 3,88 , kadınlarda yüzde 14,93; işsizken piyasayı terk etme intimali erkeklerde yüzde 13,80 , kadınlarda ise yüzde 50 'nin üzerinde olacak şekilde çarpıcı farklılıklar mevcuttur. Son satırda verilen $P_{. j}$ işgücü piyasası hallerinin ortalama ağırlıkları olarak düşünüldüğünde, kadınların yaklaşık yüzde 70 'inin piyasa dışında olduğu da zaten görülmektedir. Bu tespitler ışığında, kadınların işgücü piyasasında erkeklere kıyasla daha dezavantajlı bir konumda olduklarını söylemek mümkündür. Özellikle kriz öncesi dönemde, bir dönem işsiz olan kadınların yüzde 50'den fazlasının sonraki dönemde işgücü dışına çıkması, kadınların işgücü piyasasındaki kırılgan durumlarının oldukça iyi bir göstergesidir.

Çalışma çağındaki kadın ve erkek bireyleri, krizin hangi yönde ve boyutta etkilediği konusu genel işgücü piyasası yapısından bağımsız olarak analiz edildiğinde de dikkat çekici bulgular ortaya çıkmaktadır. İlk olarak, cinsiyet ayrımında bakıldığında, bireylerin arka arkaya iki yıl aynı işgücü durumunda bulunma olasılıkları, kriz öncesi ve ertesinde tüm çalışabilir nüfus için yapılan analizlerden ayrışmamaktadır. Her iki cinsiyet grubunda da aynı statüde kalma olasılığı ücretlilerde azalırken, kendi hesabına çalışanlarda, işsizlerde ve işgücü dışında olanlarda artmaktadır. İşsizlerin bir sonraki dönemde yine işsiz olma olasılıkları, krizle birlikte, kriz öncesi döneme kıyasla, kadınlarda 10 puan artarken, erkeklerde artı̧ 7 puanda kalmıştır. Bu durum işsizlikteki direncin, krizle birlikte, kadınlarda daha fazla arttğını göstermektedir. Bir diğer ifadeyle kadınlarda işsiz kalınan ortalama süre krizle birlikte, erkeklerde olduğundan daha fazla artmış gibi görünmektedir.

Çalışırken işsiz kalma olasılıklarına bakıldığında, ücretli/yevmiyeli çalışan kadınlarda krizle birlikte işsiz durumuna geçme olasılığı erkeklerdekine kıyaslandığında daha çarpııı bir şekilde neredeyse iki katı oranında artmış olarak görülmektedir. Nitekim, küresel ekonomik krizle birlikte Türkiye'de çalışan erkeklere kıyasla kadınların daha büyük bir bölümü işini kaybetmiştir. Bu çerçevede, kriz dönemlerinde, işverenlerin, erkeklere nazaran kadın çalışanların işlerine daha kolay son verebildikleri değerlendirmesini yapmak mümkün görünmektedir. Bu durumun ortaya çıkmasında etkili olan nedenlerin araştırılması ayrı bir çalışma konusu olmakla birlikte, kadınların daha az kritik pozisyonlarda istihdam edilmesi, kriz dönemlerinde işten daha kolay çıkarılmalarında etkili olabilir.

Kadın ve erkeklerin çalışma durumları arası geçiş olasılıkları da birbirinden ayrışmaktadır. Kadınlarda, kendi hesabına çalışma durumundan, ücretli duruma geçiş olasılığı, kriz öncesi dönemde yüzde 2,04'ten, kriz döneminde yüzde 0,58'e gerilemiştir. Kadınlardaki yaklaşık dörtte üçlük azalmaya karşlık, erkeklerde bu olasılık yüzde 7,71'den, 6,02'ye gerilemiştir. Ercan (2010)'un Türkiye işgücü piyasasında insanların kendi hesaplarına yaptıkları işlerin, ücretli işlere kıyasla daha çoğu zaman daha az nitelikli olduğu tespitinden hareketle, bu sonuç krizle birlikte kadın istihdamındaki kalite bozulmasının, erkek istihdamındakinden daha fazla olduğunu değerlendirmesi yapılabilir.

Tablolardan dikkat çeken bir diğer bulgu ise, kriz ile birlikte işsizlikten işgücüne çıkış olasıllı̆ı erkekler için hiç etkilenmezken, kadınlar için neredeyse yüzde 10 düşüş göstermiş olmasıdır. Gerek kriz öncesinde gerekse de kriz döneminde işsiz erkeklerin yaklaşık yüzde 14'ünün işgücü dışına çıktkları görülmektedir. Kadınlarda ise bu olasılık kriz öncesinde yaklaşık yüzde 52'den, krizle birlikte yüzde 43'e gerileşmiştir. Bu sonuç kriz döneminde oluşan ek çalışan etkisinin Türkiye işgücü piyasalarında kadınlar kanalıyla çok net ortaya çıktğını kanıtlamaktadır. Normal şartlar altında iş bulamadığı için işgücü dışına çıkan kadınlar, krizle birlikte iş arama süreçlerini kesintiye uğratmayıp işgücü içinde kalmışlardır. Literatürde ilave çalışan etkisi denen bu durum krizlerin işgücü piyasası üzerindeki başlıca etkilerinden biridir. Kendi hesabına çalışan erkek ve kadınların işsiz kalma olasılıkları incelendiğinde ise kriz öncesi ve kriz döneminde belirgin bir farklıık gözlemlenmemektedir. 
İşsizlikten çıkışlara bakıldığında erkeklerde ücretli/yevmiyeli işte çalışmaya başlama olasılığı kriz öncesindeki yüzde 44,03 seviyelerinden krizle birlikte yüzde 36,97'ye gerilemiştir. İşsiz erkeklerin kendi hesabına çalışmaya başlama ya da işgücü dışına çıkma olasılıkları kriz öncesi ve sonrası dönemlerde belirgin bir farklılık göstermezken, işsizlikte çakılı kalma olasılığı yüzde 32,92' den yüzde 39,59'a yükselmiştir. İşsiz kadınlarda ise, ücretli/yevmiyeli iş bulma olasılı̆̆ı kriz öncesinde ortalama yüzde 25,91 'den kriz döneminde yüzde 23,84 'e, erkeklere nazaran daha düşük bir oranda gerilemiştir.

Krizlerin işgücü piyasalarındaki etkilerinin boyut ve niteliğini belirleyen temel faktörlerden biri de eğitimdir. Genel beklenti, vasıf ya da eğitim seviyesi arttkça krizin olumsuz etkilerinden daha az etkilenileceği yönündedir. Türkiye işgücü piyasalarındaki kriz etkilerini eğitim kırılımında analiz etmeden önce, kriz öncesi dönemde var olan yapıyı değerlendirmek faydalı olacaktır. Tablo 4, 5 ve 6 sırasıyla düşük, orta ve yüksek vasıflı işgücünün 2006-2007 ile 2007-2008 ortalama ve 2008-2009 dönemi için Markov geçiş olasılıklarını göstermektedir.

Tablo 4. Markov Geçiş Olasılıkları $\left(P_{\mathrm{ij}}\right)(\%)$ - Düşük Vasıflı

\begin{tabular}{|c|c|c|c|c|c|c|c|c|}
\hline \multirow{2}{*}{$\begin{array}{l}\text { Köken/ } \\
\text { Varış }\end{array}$} & \multicolumn{4}{|c|}{ Kriz Öncesi Dönem } & \multicolumn{4}{|c|}{$\underline{\text { Kriz Dönemi }}$} \\
\hline & $S$ & SE & U & OLF & $S$ & SE & U & OLF \\
\hline $\mathbf{S}$ & 78,54 & 5,88 & 7,37 & 8,21 & 76,5 & 6,88 & 8,62 & 8,01 \\
\hline SE & 3,96 & 85,14 & 1,39 & 9,53 & 2,45 & 89,29 & 1,26 & 6,99 \\
\hline U & 39,72 & 9,05 & 28,75 & 22,50 & 30,2 & 10,51 & 34,68 & 24,61 \\
\hline OLF & 3,06 & 5,42 & 1,47 & 90,07 & 2,52 & 4,01 & 1,66 & 91,82 \\
\hline $\mathbf{P}_{. \mathrm{j}}$ Total & 19,49 & 28,24 & 3,64 & 48,63 & 18,89 & 27,98 & 4,31 & 48,82 \\
\hline
\end{tabular}

Kaynak: GYKA 2006-2009 (Yalnızca panel gözlemler) ve yazarın kendi hesaplamaları. Notlar: Bakınız Tablo 1.

Tablo 5. Markov Geçiş Olasılıkları $\left(P_{\mathrm{ij}}\right)(\%)$ - Orta Vasıflı

\begin{tabular}{|l|cccccccc|}
\hline \multirow{2}{*}{$\begin{array}{l}\text { Köken/ } \\
\text { Varış }\end{array}$} & \multicolumn{3}{|c}{ Kriz Öncesi Dönem } & & \multicolumn{4}{c|}{ Kriz Dönemi } \\
\cline { 1 - 7 } S & S & SE & U & OLF & S & SE & U & OLF \\
SE & 86,72 & 3,52 & 5,13 & 4,63 & 80,43 & 4,67 & 9,41 & 5,49 \\
U & 8,64 & 81,81 & 2,58 & 6,99 & 6,57 & 86,22 & 2,4 & 4,8 \\
OLF & 37,71 & 6,69 & 32,42 & 23,18 & 33,72 & 6,45 & 38,71 & 21,11 \\
P.j Total & 6,49 & 3,67 & 4,93 & 84,93 & 4,86 & 2,66 & 5,41 & 87,07 \\
\hline
\end{tabular}

Kaynak: GYKA 2006-2009 (Yalnızca panel gözlemler) ve yazarın kendi hesaplamaları. Notlar: Bakınız Tablo 1.

Tablo 6. Markov Geçiş Olasılıkları $\left(P_{\mathrm{ij}}\right)(\%)$ - Yüksek vasıflı

\begin{tabular}{|c|c|c|c|c|c|c|c|c|}
\hline \multirow{2}{*}{$\begin{array}{l}\text { Köken/ } \\
\text { Varış }\end{array}$} & \multicolumn{4}{|c|}{ Kriz Öncesi Dönem } & \multicolumn{4}{|c|}{$\underline{\text { Kriz Dönemi }}$} \\
\hline & $\mathbf{S}$ & SE & U & OLF & $S$ & SE & U & OLF \\
\hline $\mathbf{S}$ & 90,79 & 1,93 & 3,12 & 4,17 & 90,19 & 1,71 & 4,85 & 3,25 \\
\hline SE & 9,55 & 84,13 & 2,01 & 4,31 & 9,09 & 85,15 & 1,52 & 4,24 \\
\hline U & 41,54 & 7,40 & 24,95 & 26,11 & 38,17 & 4,84 & 34,95 & 22,04 \\
\hline OLF & 9,41 & 2,28 & 6,37 & 81,96 & 7,87 & 3,09 & 7,58 & 81,46 \\
\hline $\mathbf{P}_{. \mathrm{j}}$ Total & 56,44 & 13,00 & 5,20 & 25,37 & 57,64 & 11,68 & 7,05 & 23,63 \\
\hline
\end{tabular}

Kaynak: GYKA 2006-2009 (Yalnızca panel gözlemler) ve yazarın kendi hesaplamaları. Notlar: Bakınız Tablo 1. 
Yalnızca kriz öncesi dönem istatistikleri ele alındığında öne çıkan birkaç yapısal özellik şöyle sıralanabilir: Her hangi bir ücretli/yevmiyeli çalışan kişinin düşük vasıflı olma ihtimali yüzde 19,49 iken; orta vasıflı olma ihtimali yüzde 31,23, yüksek vasıflı olma ihtimali yüzde 56,44 'tür. Yani bir kişinin eğitim ve beceri seviyesi arttkça, ücretli/yevmiyeli olarak çalışma olasılığı da yükselmektedir. Bu bulgunun tam tersini kendi hesabına çalışanlar için söylemek mümkündür: Eğitim ve beceri seviyesi arttkça kendi hesabına çalışma olasılı̆̆ı düşmektedir. Benzer şekilde, işgücü dışında kalma olasılığı da eğitim ile birlikte çarpıcı bir şekilde düşüş göstermektedir. Düşük vasıflı grubunda işgücü dışında olma olasılığı yüzde 48,63 iken yüksek vasıf grubunda bu oran yüzde 25,37'ye kadar gerilemektedir.

Ücretli/yevmiyeli çalışma statüsünde çalışanların bu şekilde çalışmaya devam etmesi olasılığı vasıf ile birlikte artarken, işsiz kalma ve kendi hesabına çalışma statüsüne geçme olasılıkları eğitimle birlikte önemli ölçüde düşüş göstermektedir. Ücretli/yevmiyeli kesimin işgücüne çıkış olasılığı düşük vasıflı bireylerde orta ve yüksek vasıfılardakinin yaklaşık iki katıdır. Bir diğer bulgu, her iki grupta da çalışanlar için işgücü dışına çıkma olasılı̆̆ının eğitim ile ters orantılı olmasıdır.

İşsizlik halinin sürmesi ya da bir diğer deyişle işsiz kalmaya devam edilmesi olasılığı yüzde 28,75 ile düşük vasıflı işgücünde en yüksek; yüzde 24,95 ile yüksek vasıflı işgücünde en düşük değerini almaktadır.

Eğitim/vasıf düzleminde Türkiye emek piyasasındaki işgücü hareketliliğini yorumladıktan sonra, ekonomik krizin bu yapıyı hangi ölçüde ve şekilde değiştirdiğini değerlendirmek önem taşımaktadır. Nitekim kriz öncesi ve ertesi dönemi Markov geçiş olasılıkları eğitim kırılımında kıyaslandığında, çarpıcı farklılıklar sergilemektedir. İlk dikkat çeken nokta, her üç vasıf grubundaki ücretli/yevmiyeli çalışanlarda işsiz kalma olasılığının krizle birlikte artmış olduğudur. Bu artış, düşük ve yüksek vasıfılarda 1 puan civarında, orta vasıf grubunda yaklaşık 5 puan olmuştur. Oransal kıyaslama yapıldığında tablo daha net bir resim ortaya koymaktadır. Orta vasıflı olan ücretli/yevmiyeli çalışanların işsiz kalma olasılığı kriz döneminde yüzde 50'ye yakın, yüksek vasıfılarınki yaklaşık yüzde 25 artı̧̧ göstermiştir. Düşük vasıfılarda ise bu yükseliş daha sınırlı olarak gerçekleşmiştir.

Bir diğer dikkat çeken bulgu, ücretli/yevmiyeli çalışma statüsünde kalma olasılığının kriz döneminde yüksek vasıfılar için hemen hemen hiç değişmezken, düşük ve orta vasıf gruplarında düşüş göstermiş olduğudur. Bu bulgu, özel sektörde krizle mücadele kapsamında yapılan işten çıkarmalardan en az etkilenenlerin yüksek eğitim seviyesine sahip işgücü olduğuna işaret etmektedir. Bir diğer deyişle, kriz dönemlerinde eğitim Türkiye işgücü piyasasında bireylerin iş kaybetme riskini azaltmaktadır.

İşsizlikten çıkarak ücretli/yevmiyeli bir çalışan olma olasılığı da her üç vasıf grubu için kriz döneminde düşüş göstermiştir. Bu durum, yüzde 39,72'den 30,2'ye düşerek en belirgin olarak düşük vasıfılarda kendini göstermektedir. Söz konusu olasılık, orta vasıflılarda yüzde 37,71'den 33,72'ye; yüksek vasıfılarda yüzde 41,54'ten 38,17'ye gerilemiştir. Yine görüleceği üzere, kriz döneminde işsizlerin ücretli bir iş bulma olasılığı en az zararı yüksek eğitim seviyesindeki bireyler grubunda görmüştür. Bu bulgu da, bir önceki bulgu gibi, eğitimin kriz dönemlerinde emniyet tamponu oluşturduğuna işaret etmektedir.

Kriz döneminde işsizlerin kendi hesabına çalışma statüsüne geçiş olasılığında belirgin bir vasıf ilişkisi gözlemlenmemektedir. İşsizlikten kendi hesabına çalışmaya geçme olasılığı düşük vasıfılarda 1,5 puan civarında artmış, orta vasıfılarda 0,2; yüksek vasıfılarda 2,5 puan azalmıştır. Bulgular bütünüyle değerlendirildiğinde, eğitim/vasıf boyutunun işgücü piyasası dinamiklerini, kendi hesabına çalışanlardan ziyade ücretli/yevmiyeli çalışanlar kanalıyla belirgin bir şekilde etkilediğini göstermektedir.

İşgücü dışında olma durumundan piyasaya girme olasılıklarına bakıldığında da krizle birlikte tüm gruplar için ücretli/yevmiyeli işe yerleşme olasılığının azaldığı görülmektedir. Bu azalma tüm vasıf grupları için yakın değerler almıştır. İşücü dışında kalma durumunun devam etmesi olasılığı da orta vasıfılarda yüzde 84,93'ten 87,07'ye yükselirken, düşük ve yüksek eğitim sınıflarında da krize bağlı olarak belirgin bir değişiklik kaydetmemiştir.

Türkiye işgücü piyasalarındaki işgücü geçişkenliğini yaş grupları kırılımında incelemek de önem arz etmektedir. Kriz etkisini değerlendirmeden önce, işgücü hareketliliği farklı yaş grupları için ne şekilde benzerlik/farklııı göstermektedir sorusunun cevabını tartışmak faydalı olacaktır. Yaş gruplarını 15-24, 25-34, 
35-54 ve 55-64 olarak belirlemek suretiyle, işgücü piyasasına yeni girenler, gençler, orta yaşlılar ve ileri yaşılar için analiz yapılması hedeflenmiştir. Tablo 7, 8, 9 ve 10, 2006-2007 ve 2007-2008 yılları arası işgücü piyasaları durumları arasındaki geçiş olasılıklarının ortalamaları ile 2008-2009 arası geçiş olasılıklarını her yukarıda verilen yaş grupları sıralaması ile göstermektedir.

Tablo 7. Markov Geçiş Olasılıkları $\left(P_{i j}\right)(\%)$ - 15-24 Yaş

\begin{tabular}{|l|cccccccc|}
\hline \multirow{2}{*}{$\begin{array}{l}\text { Köken/ } \\
\text { Varış }\end{array}$} & \multicolumn{3}{|c}{ Kriz Öncesi Dönem } & & \multicolumn{4}{c|}{ Kriz Dönemi } \\
\cline { 1 - 8 } S & S & SE & U & OLF & S & SE & U & OLF \\
SE & 77,35 & 3,04 & 8,89 & 10,74 & 74,42 & 4,67 & 11,68 & 9,23 \\
U & 9,03 & 75,30 & 2,87 & 12,81 & 7,2 & 80,25 & 3,09 & 9,47 \\
OLF & 40,09 & 6,27 & 27,98 & 25,67 & 31,66 & 8,88 & 35,21 & 24,26 \\
P.j Total & 8,29 & 4,43 & 5,67 & 81,62 & 5,74 & 3,46 & 6,07 & 84,73 \\
& 24,08 & 13,57 & 7,69 & 54,68 & 23,13 & 13,29 & 9,36 & 54,23 \\
\hline
\end{tabular}

Kaynak: GYKA 2006-2009 (Yalnızca panel gözlemler) ve yazarın kendi hesaplamaları. Notlar: Bakınız Tablo 1.

Tablo 8. Markov Geçiş Olasılıkları $\left(\mathrm{P}_{\mathrm{ij}}\right)(\%)$ - 25-34 Yaş

\begin{tabular}{|c|c|c|c|c|c|c|c|c|}
\hline \multirow{2}{*}{$\begin{array}{l}\text { Köken/ } \\
\text { Varış }\end{array}$} & \multicolumn{4}{|c|}{ Kriz Öncesi Dönem } & \multicolumn{4}{|c|}{ Kriz Dönemi } \\
\hline & S & SE & U & OLF & S & SE & $\mathbf{U}$ & OLF \\
\hline $\mathbf{S}$ & 88,14 & 4,01 & 5,03 & 2,83 & 84,53 & 4,67 & 7,35 & 3,45 \\
\hline SE & 7,80 & 83,14 & 2,03 & 7,04 & 6,03 & 86,97 & 1,69 & 5,31 \\
\hline U & 43,28 & 8,13 & 30,59 & 18,00 & 41,82 & 5,09 & 37,09 & 16 \\
\hline OLF & 3,97 & 4,86 & 3,35 & 87,83 & 3,78 & 3,85 & 3,58 & 88,79 \\
\hline $\mathbf{P}_{. \mathrm{j}}$ Total & 39,20 & 21,22 & 5,32 & 34,27 & 39,71 & 19,99 & 6,87 & 33,43 \\
\hline
\end{tabular}

Kaynak: GYKA 2006-2009 (Yalnızca panel gözlemler) ve yazarın kendi hesaplamaları. Notlar: Bakınız Tablo 1.

Tablo 9. Markov Geçiş Olasılıkları $\left(P_{\mathrm{ij}}\right)(\%)$ - 35-54 Yaş

\begin{tabular}{|c|c|c|c|c|c|c|c|c|}
\hline \multirow{2}{*}{$\begin{array}{l}\text { Köken/ } \\
\text { Varış }\end{array}$} & \multicolumn{4}{|c|}{ Kriz Öncesi Dönem } & \multicolumn{4}{|c|}{$\underline{\text { Kriz Dönemi }}$} \\
\hline & $\mathbf{S}$ & SE & U & OLF & $\mathbf{S}$ & SE & $\mathbf{U}$ & OLF \\
\hline$S$ & 85,16 & 4,27 & 4,66 & 5,92 & 83,86 & 4,5 & 6,29 & 5,35 \\
\hline SE & 4,18 & 87,66 & 1,62 & 6,55 & 3,18 & 90,43 & 1,37 & 5,03 \\
\hline $\mathbf{U}$ & 37,29 & 10,52 & 30,06 & 22,15 & 27,78 & 9,63 & 38,52 & 24,07 \\
\hline OLF & 3,58 & 4,76 & 1,53 & 90,13 & 3,19 & 3,74 & 2,39 & 90,69 \\
\hline $\mathbf{P}_{\mathrm{j} j}$ Total & 28,52 & 28,31 & 3,38 & 39,80 & 29,18 & 27,66 & 4,62 & 38,54 \\
\hline
\end{tabular}

Kaynak: GYKA 2006-2009 (Yalnızca panel gözlemler) ve yazarın kendi hesaplamaları. Notlar: Bakınız Tablo 1. 
Tablo 10. Markov Geçiş Olasılıkları $\left(P_{\mathrm{ij}}\right)(\%)$ - 55-64 Yaş

\begin{tabular}{|c|c|c|c|c|c|c|c|c|}
\hline \multirow{2}{*}{$\begin{array}{c}\text { Köken/ } \\
\text { Varış }\end{array}$} & \multicolumn{4}{|c|}{ Kriz Öncesi Dönem } & \multicolumn{4}{|c|}{ Kriz Dönemi } \\
\hline & S & SE & $\mathbf{U}$ & OLF & S & SE & U & OLF \\
\hline $\mathbf{S}$ & 63,90 & 5,57 & 4,15 & 26,40 & 59,74 & 9,09 & 7,14 & 24,03 \\
\hline SE & 1,33 & 83,41 & 0,36 & 14,90 & 0,18 & 89,15 & 0,74 & 9,93 \\
\hline U & 18,83 & 6,69 & 21,33 & 53,16 & 10,53 & 10,53 & 36,84 & 42,11 \\
\hline OLF & 1,62 & 4,55 & 0,90 & 92,95 & 1,29 & 3,27 & 0,84 & 94,6 \\
\hline $\mathbf{P}_{\mathrm{j} j}$ Total & 6,27 & 26,63 & 1,35 & 65,76 & 5,56 & 26,62 & 1,95 & 65,87 \\
\hline
\end{tabular}

Kaynak: GYKA 2006-2009 (Yalnızca panel gözlemler) ve yazarın kendi hesaplamaları.

Notlar: Bakınız Tablo 1.

Ücretli/yevmiyeli çalışanların bu statüde çalışmaya devam etme olasılı̆̆ı yaş grupları ile ters $U$ şeklinde bir ilişkinin varlığına işaret etmektedir. Bu olasılık piyasaya yeni giren 15-24 grubu için yüzde 77,35, $25-34$ arası gençler için yüzde 88,14 , orta yaş grubu için yüzde 85,16 ve ileri yaş grubu için yüzde 63,90 olarak hesaplanmıştır.

Kendi hesabında çalışanlarda aynı statüde kalma olasılığı yüzde 75,30 ile yine 15-24 yaş grubu için en düşük değerinin alırken, ileri yaş gruplarında belirgin bir farklılık göstermeyip yüzde 83-87 bandında seyretmektedir. İssizlik halinin sürmesi olasılığı ise en düşük olarak ileri yaş grubu için gerçekleşirken, diğer gruplarda benzer olup, yüzde 28-30 aralığındadır. İşgücü dışında olma durumunun devam etmesi olasılığı ise yaş dağııımı boyunca giderek artmaktadır.

İssizlikten çalışma durumuna geçiş olasılıkları değerlendirildiğinde, ücretli/yevmiyeli bir işte çalışmaya geçme olasılı̆̆ı 25-34 yaş grubu için en yüksek değerini almaktadır. İleri yaş grubundaysa bu değer neredeyse dörtte birine düşerek yüzde 18 olarak ortaya çıkmaktadır. İşsizlerin kendi hesabına çalışmaya başlaması olasılığı ise, yaş ile ters $\mathrm{U}$ şeklinde bir ilişki ortaya koymaktadır.

Yaş gruplarının işgücü piyasasındaki dağılımları incelendiğinde, 15-24 arası bireylerin yüzde 54,68'nin piyasa dışında kaldığını, yüzde 24,08'inin ücretli/yevmiyeli, yüzde 13,57'sinin kendi hesabına çalıştğını görmekteyiz. İşsizlik oranı ise bu grup için yüzde 7,69 olarak ortaya çıkmaktadır. 25-34 yaş arası genç işgücü ise yüzde 39,20 olasılıkla ücretli/yevmiyeli, yüzde 21.22 olasılıkla kendi hesabına çalışıyor diye yorumlanabilir. Bu grup için işsizlerin oranı yüzde 5,32, işgücü dışında olanlarınki ise yüzde 34,27 'dir. Orta yaş grubuna dahil kişilerde işgücü dışında olma yine en yüksek olasılı̆̆ı taşımaktadır. Ardından yüzde 28,52 ile ücretli/yevmiyeli ve yüzde 28,31 ile kendi hesabına çalışıyor olma ihtimalleri gelmektedir. İşsizler bu grubun yanlızca yüzde 3,38'ini oluşturmaktadır. Son olarak, 55-64 yaş grubuna bakıldığında, işgücü dışında olanların oranı oldukça yüksek olup, yüzde 65,76 olarak hesaplanmıştır. Geriye kalanların yüzde 26,63'ü kendi hesabına, yüzde 6,27'si ücretli/yevmiyeli çalışanlardan oluşmaktadır. İşsizler ise yalnızca örneklemin yüzde $1,35^{\prime}$ ine tekabül etmektedir.

Ekonomik krizle birlikte yukarıda bahsedilen tespitlerin bazıları önemli ölçüde değişiklik göstermiştir. Illk olarak, tüm yaş grupları için ücretli/yevmiyeli çalışma statüsünü koruma olasılığı 3-4 puan civarında düşmüş olarak görülmektedir. Bu azalmanın büyük oranda karşılığı ücretli/yevmiyeli çalışma statüsünden işsizliğe geçme olasılığındaki artş̧ta net olarak görülebilmektedir. Öte yandan, kendi hesabına çalışanlarda kriz döneminde işsiz kalma olasılığının artma ya da azalma yönünde belirgin bir etkisinin olmadığını tüm yaş grupları için söylemek mümkündür. Bir diğer deyişle, kriz yaş grupları üzerinden yapılan analizde de kendi hesabına çalışanlardan ziyade ücretli/yevmiyeli çalışanlar kanalında etkisini hissettirmiştir.

Krizin bir diğer belirgin etkisi de tüm yaş grupları için, herhangi bir diğer işgücü piyasası durumundan ücretli/yevmiyeli çalışma statüsüne geçme olasılığını düşürmesi olmuştur.

Kriz öncesi ve kriz dönemindeki işsizlikten çıkışa dair Markov geçiş olasılıkları da önemli bulgular ortaya koymaktadır. İssizlerin ücretli/yevmiyeli işe yerleşme olasılığı tüm yaş gruplarında düşmüştür. Söz konusu düşüş, diğer gruplarda yaklaşık olarak yüzde 10 iken, 25-34 yaş grubunda daha sınırlı olarak 
gerçekleşmiş ve 1,5 puanda sınırlı kalmıştır. Bu bulgu, daha öncekileri de destekler şekilde krizin ücretli çalışılan işlerde işten çıkarma, yeni açılan iş pozisyonlarında daralma, ücret kesilmeleri gibi uygulamaların kriz ertesinde çok yaygınlaşmış olmasından kaynaklanmaktadır.

Benzer şekilde, işsiz bir bireyin kendi hesabına çalışma durumuna geçme olasılığı, 55-64 yaş grubu dışındaki tüm gruplarda azalmıştır.

Illeri yaştaki işgücünün kriz ile birlikte işsizlikten kendi hesabına çalışmaya geçme olasılığının yüzde 6,69'dan 10,53'e yükselmesi ilginç bir bulgudur. Bu durum, krizle birlikte içeriğinde büyük oranda kayıtdışı istihdam barındıran kendi hesabına çalışma durumunun bu bireyler için son çare olarak devreye girdiğine işaret etmektedir. İşsiz insan sayısının ve işsiz kalma süresinin kriz ile birlikte artmasına bağı olarak, işgücü piyasasında en dezavantajlı gruplardan biri olan ileri yaş grubundaki bireyler kayıtdışı çalışmaya yönelmişlerdir. Nitekim Türkiye işgücü piyasalarında kriz ertesinde kayıtdışı istihdamın artmış olduğu pek çok çalışma tarafindan ortaya konmuştur (Ercan, 2010).

Öte yandan, işsizlik halinin devam etme olasılığı da beklenildiği üzere tüm yaş grupları için çarpıcı bir oranda artmıştır. Kriz öncesi ve kriz dönemi Markov olasılıkları oranlandığında, 54-65 yaş grubunda işsizlikten çıkılamama ihtimali neredeyse yüzde 75 artı̧ göstermiştir. Diğer gruplarda ise, 15-24 yaş grubunda yüzde $27,98^{\prime}$ den $35,21^{\prime}$ e, $25-34$ yaş grubunda yüzde $30,59^{\prime}$ dan $37,09^{\prime}$ a ve $35-54$ yaş grubunda 30,06 'dan $38,52^{\prime}$ ye yaklaşık 7-8 puanlık yükselme kaydedilmiştir. Bu bulgu, işgücü piyasasında kriz dönemlerinde iş bulmak açısından en dezavantajlı grupta olanların ileri yaştaki bireyler olduğuna işaret etmektedir. Önceki paragrafta da belirtildiği gibi, bu durumdaki bireyler kayıtdışı istihdama yönelerek, krizle birlikte kayıtdışılık oranlarının artmasının altındaki temel dinamikleri oluşturmuşlardır.

Son olarak, kriz döneminde yine beklentiyi destekleyecek şekilde, işgücü dışında olan bireylerin ücretli/yevmiyeli çalışmaya başlaması olasılığı tüm gruplarda, işsizlikten geçişlerdeki kadar belirgin olmamakla birlikte, düşüş kaydetmiştir. Bu azalma en belirgin olarak yaklaşık 3 puan ile 15-24 yaş arası gençler için gözlenmiştir.

\section{Sonuç}

Küresel ekonomik kriz, Türkiye işgücü piyasası üzerinde, farklı işgücü statüleri arasındaki geçişkenlik olasılıklarını değiştirmek suretiyle hem toplamda, hem cinsiyet, yaş ve eğitim ayrımlarında çeşitli niteliklerde ve boyutlarda etkili olmuştur. Ücretli/yevmiyeli çalışma, kendi hesabına çalışma, işsiz ve işgücü dışında olma olarak belirlenen dört farklı istihdam durumu arasındaki yıllık bireysel geçişlerin Markov olasılık istatistikleri analizi bu çerçevede pek çok bulgu ortaya çıkarmıştır.

İlk olarak, ücretli çalışanların işsiz statüsüne geçiş olasılıklarının kriz öncesine kıyasla, kriz döneminde arttğı bulgusu göze çarpmaktadır. Nisan 2009 itibariyle 1.2 milyon kişinin kriz nedeniyle işini kaybetmiştir. Buna paralel bir diğer gözlem, işsiz durumundan, ücretli çalışan statüsüne geçiş olasılığındaki gerilemedir. İkinci önemli tespit, ekonominin istikrarlı olduğu dönemlerde, kendi hesabına çalışanların, ücretli bir işe geçme olasılıkları; ücretli çalışanların, kendi hesabına çalışan durumuna geçmeleri olasılığından daha yüksektir. Kriz döneminde ise tam tersi olmuştur. Ücretliden, kendi hesabına çalışan statüsüne geçiş olasılığı; kendi hesabına çalışandan, ücretli statüsüne geçiş olasılığının altına inmiştir. Bu durum krizin istihdamın niteliği üzerinde de olumsuz bir etkiye neden olduğunun göstermektedir. Üçüncü öne çıkan bulgu ise, işgücü dışında olma durumundan ücretli ya da kendi hesabına çalışan durumununa geçiş olasılıklarının düşmesi ve buna karşılık işsiz durumuna geçiş olasılığının sınırlı da olsa artmasıdır. Kriz döneminde işgücüne dahil olan kesimin, kriz öncesine kıyasla daha düşük bir bölümü istihdam tarafinda geçerken, daha büyük bir bölümü işsiz tarafina geçmektedir.

Kriz öncesine kıyasla, kriz ertesinde, bireylerin arka arkaya iki yıl aynı işgücü durumunda bulunma olasılıkları, kadın ve erkek ayrımında, genel eğilim olarak tüm çalışabilir nüfus için yapılan analizlerden ayrışmamaktadır. Her iki cinsiyet grubunda da aynı statüde kalma olasılı̆ı ücretlilerde azalırken, kendi hesabına çalışanlarda, işsizlerde ve işgücü dışında olanlarda artmaktadır. İşsizlerin bir sonraki dönemde yine işsiz olma olasılıkları, krizle birlikte, kriz öncesi döneme kıyasla, kadınlarda 10 puan artarken, erkeklerde artı̧ 7 puanda kalmıştr. Bu işsizlikteki direncin, kadınlar söz konusu olduğunda daha fazla arttı̆ı̆ı göstermektedir. 
Öte yanda, aynı işgücü durumunu koruma olasılıkları itibariyle kadın ve erkeklerde ciddi bir farklıık gözlenmezken, kadın ve erkeklerin işgücü durumları arası geçiş olasılıkları farklılaşmaktadır. Kadınlarda, kendi hesabına çalışma durumunda, ücretli duruma geçiş olasılığı, kriz ile birlikte yaklaşık dörtte üçlük azalma kaydetmiştir. Buna karşılık, erkekler için geçerli olan söz konusu olasılık değişimi yüzde 25 ile sınırlı olmuştur. Insanların kendi hesaplarına yaptıkları işlere bakıldığında, ücretli işlere kıyasla daha az nitelikli oldukları görülmektedir. Bu çerçevede, krizle birlikte kadın istihdamındaki kalite bozulmasının, erkek istihdamındaki bozulmaya kıyasla daha yüksek bir oranda gerçekleştiğini söylemek mümkündür.

Kriz etkilerinin eğitim boyutuna bakıldığında her üç vasıf grubundaki ücretli/yevmiyeli çalışanlarda işsiz kalma olasııı̆ının krizle birlikte artmış olduğu görülmüştür. Ücretli/yevmiyeli çalışma statüsünde kalma olasılığının kriz döneminde yüksek vasıfılar için hemen hemen hiç değişmezken, düşük ve orta vasıf gruplarında düşüş göstermiş olması özel sektörde krizle mücadele kapsamında yapılan işten çıkarmalardan en az etkilenenlerin yüksek eğitim seviyesine sahip işgücü olduğuna işaret etmektedir. Buna benzer şekilde, kriz döneminde işsizlerin ücretli bir iş bulma olasılığı en az zararı yüksek eğitim seviyesindeki bireyler grubunda görmüştür. Bu sonuçlar, kriz dönemlerinde eğitimin Türkiye işgücü piyasasında bir nevi emniyet tamponu görevi gördüğüne işaret etmektedir. Bulgular bütünüyle değerlendirildiğinde, eğitim/vasıf boyutunun işgücü piyasası dinamiklerini, kendi hesabına çalışanlardan ziyade ücretli/yevmiyeli çalışanlar kanalıyla belirgin bir şekilde etkilediğini göstermektedir.

Son olarak, Markov geçiş olasıııkları analizi farklı yaş grupları için tekrarlandığında, tüm yaş grupları için ücretli/yevmiyeli çalışma statüsünü koruma olasılığının düştüğünü ve bunun büyük oranda ücretli/yevmiyeli çalışma statüsünden işsiziiğe geçme olasııı̆̆ındaki artışına dönüştüğünü göstermektedir. Illeri yaştaki işgücünün kriz ile birlikte işsizlikten kendi hesabına çalışmaya geçme olasııı̆ının iki katına çıkması da dikkat çekici bir bulgu olup, krizle birlikte içeriğinde büyük oranda kayıtdışı istihdam barındıran kendi hesabına çalışma durumunun bu bireyler için son çare olarak devreye girdiğine işaret etmektedir. İşsiz insan sayısının ve işsiz kalma süresinin kriz ile birlikte artmasına bağıı olarak, pek çok çalışma tarafindan önceden ortaya konmuş olan kayıtdışı istihdamın krizle artth̆̆ı tespiti desteklenmiştir.

Çalışmanın sonuçlarından hareketle üç temel politika önermesi yapılabilir. İlk olarak, kadınların, diğer pek çok ülke örneğinde de görüldüğü gibi, işgücü piyasasında olumsuz etkilere daha duyarlı olduğu ve ilk etkilenenlerden olduğu sonucu, kamu politikaları tasarlanırken kadınlar için eğitim ve öğretim, çocuk bakımı vb. olanaklarının iyileştirilmesinin önemine işaret etmektedir. Benzer şekilde, daha sağlıklı işgücü piyasası dinamiklerine sahip olabilmek için işgücü dışında yer alan kesimin politika yapıcıları tarafindan daha detaylı şekilde incelenmesi, piyasaya dahil olmalarının sağlanması da büyük önem arz etmektedir. Son olarak, Türkiye'deki işgücünün eğitim ve nitelik seviyelerinin artırılması yönünde atılacak her adım, piyasanın krizlere daha az duyarlı ve daha sağlam temellere oturmasına sebep olacaktır. Gelecek çalışmalarda, bu çalışmada ortaya çıkan bulguların çoklu regresyon modelleri ve daha detaylı açıklayıcı değişkenler kullanılarak araştırılması Türkiye işgücü piyasası dinamikleri literatürüne katkı yapacaktır.

\section{Kaynaklar}

Alcan, D., Can, R., \& Pektaş, B. (2015). Türkiye işgücü piyasasında hareketlilik: Mikro veriye dayalı analiz. Kalınma $\begin{array}{lllll}\text { Bakanlığı Ekonomi Çalışma } & \text { Tebliğleri } & \text { Serisi } & \text { No: } & \text { 2015/1. }\end{array}$ http://www.kalkinma.gov.tr/Lists/Yaynlar/Attachments/651/Türkiye i̇şgücü Piyasasında Hareketlilik Mikro Veriye Dayalı Analiz.pdf.

Bernabè, S., \& Stampini, M. (2009). Labour mobility during transition: Evidence from Georgia. Economics of Transition, 17(2), 377-409.

Bosch, M., \& Maloney, W. (2007). Gross worker flows in the presence of informal labour markets. Evidence from Mexico, 1987-2002. IZA Discussion Paper No. 2864.

Bosch, M., \& Maloney, W. (2010). Comparative analysis of labor market dynamics using Markov processes: An application to informality. Labour Economics, 17(4), 621-631. 
Duryea, S., Marquez, G., Pages, C.,\& Scarpetta, S. (2006). For better or for worse? Job and earnings mobility in nine middle and low income countries. Brookings Trade Forum, 187203.

Ercan, H. (2010). Küresel krizin istihdama etkisi: Türkiye. In Kriz ve Türkiye: Kriz Tedbirlerinin Etki Değerlendirilmesi. ILO Yayınları, Ankara. http://staging.ilo.org/public/libdoc/ilo/2010/110B09_293_turk.pdf.

Erdoğdu, S. (2010). Küresel krizin istihdama etkileri ve kriz karşıt işgücü piyasası önlemleri. Memleket Siyaset Yönetim, $2010-12$

Fabrizi, E., \& Mussida, C. (2009). The determinants of labour market transitions. Giornale degli Economisti e Annali di Economia, 68(2), 233-265.

Gong, X., Van Soest, A., \& Villagomez, E. (2004). Mobility in the urban labor market: A panel data analysis for Mexico. Economic Development and Cultural Change, 53(1), 1-36.

Gökbunar, A. R., Duramaz, S., \& Duramaz, S. (2016). Küresel krizin işgücü piyasaları üzerindeki etkisinin karşılaştırılması: İspanya ve Türkiye örneği.

https://www.academia.edu/21562994/Küresel_Krizin_İşgücü_Piyasaları_Üzerindeki_Etkisinin_Karşılaştırılması_İspany a_ve_Türkiye_Örneği

Kaya Bahçe, S., \& Memiş, E. (2014). The uncounted who wish to work - distinct to the unemployed or similar?, Sosyeekonomi, 2014 (1), 305-333.

Kılıç, C., \& Bülbül, O. G. (2012). Küresel kriz sürerken Türkiye işgücü piyasası temel göstergelerindeki değişimler. http://okanguraybulbul.com.tr/wp-content/uploads/2012/12/8.pdf.

Maloney, W. (1999). Does informality imply segmentation in urban labor markets? Evidence from sectoral transitions in Mexico. World Bank Economic Review, 13(3), 275-302.

Tansel A., \& Kan, E. Ö. (2012). Labor mobility across the formal/iınformal divide in Turkey: Evidence from individual level data. IZA Discussion Paper No: 6271.

Tasci, H. M., \& Tansel, A. (2005). Unemployment and transitions in the Turkish Labor market: Evidence from individual level data. IZA Discussion Papers 1663. http://ftp.iza.org/dp1663.pdf.

UNCTAD United Nations Conference on Trade and Development (2008), Will we never learn?, UNCTAD Policy Briefs, http://www. unctad.org/en/docs/presspb20085_en.pdf .

Yaprak, Ş. (2009). Ekonomik krizlerin istihdama yansıması. Ekonomi Bilimleri Dergisi, 1 (2), $41-54$. http://sobiad.org/eJOURNALS/dergi_EBD/arsiv/ebd-2009/04senol_yaprak.pdf.

Yeldan, E. (2010). Küresel kriz ve Türkiye: Mali canlandırma önlemlerinin istihdam ve işgücü piyasaları üzerindeki etkilerinin makroekonomik değerlendirilmesi. In Kriz ve Türkiye: Kriz Tedbirlerinin Etki Değerlendirilmesi. ILO Yayınları, Ankara http://staging.ilo.org/public/libdoc/ilo/2010/110B09_293_turk.pdf. 